- Valleas, T., Petmezaki, S., and Doxiadis, S. A., Bilirubin Metabolism in the Newborn, ed. D. Bergsma and D. Y-Y Hsai, p. 46. Baltimore, Williams and Wilkins, 1970.

Reid, M., et al., Lancet, 1972, 1, 879.

Sisson, T. R. C., et al., Fournal of Pediatrics, 1971, 79, 904

Ostrow, J. D., in Progress in Liver Disease, Vol. 4, ed. H. Popper and F. Schaffner, p. 447. New York, Grune and Stratton, 1972.

F. Schaffner, p. 447. New York, Grune

8 British Medical fournal, 1972, 2,62 .

- Wong, Y. K., and Wood, B. S. B., Archives of Disease in Childhood, 1973, 48, 704 .

10 Valdes, O. S., et al., Fournal of Pediatrics, 1971, 79, 1015.

11 Blackburn, M. G., Orzalesi, M. M., and Pigram, P., Pediatrics, 1972, 49, 110 .

$12 \mathrm{Oh}, \mathbf{W}$., and Karecki, H., American fournal of Diseases in Childhood, 1972, $124,230$.

18 Washington, J. L., Brown, A. W., and Starrett, A. L., Pediatrics, 1972, 49, 279.

14 Rubalttelli, F. E., and Largajolli, G., Acta Paediatrica Scandinavica, 1973, 62, 146.

16 Spennati, G., Girotti, F., and Orzalesi, M. M., Fournal of Pediatrics $1973,82,286$.

16 Giunta, F., fournal of American Medical Association, 1969, 208, 1703.

17 Woody, M. C., and Brodkey, M. J., Fournal of Pediatrics, 1973, 82, 1042.

18 Kopelman, A. E., Brown, R. S., and Odell, G. B., Fournal of Pediatrics,

10 Odell, G. B., Brown, R. S., and Kopelman, A. E., Fournal of Pediatrics, $1972,81,473$.

${ }^{20}$ Keenan, W. J., et al., Pediatrics, 1972, 49, 652.

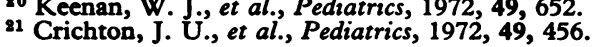

\section{Volume-dependent Essential Hypertension?}

Though an increase of sodium in the diet can expand the volume of plasma, blood, and extracellular fluid and raise blood pressure in animals, ${ }^{12}$ the role of volume expansion in clinical hypertension is not clear. Certainly there are hypertensive syndromes in which volume is expanded. Chronic renal failure, ${ }^{3}{ }^{4}$ the hypertension which sometimes develops after bilateral nephrectomy, ${ }^{5}{ }^{6}$ and primary hyperaldosteronism ${ }^{78}$ are examples, and in each instance reduction of volume is associated with a fall of arterial pressure. But in contrast there are occasional cases of severe or malignant hypertension with depletion of sodium and water and reduction of volume. ${ }^{9} 10$

Between these extremes lie the large group of patients with essential hypertension. Most studies of the condition indicate that plasma or blood volume is not increased. Some show mean values for hypertensive patients that are significantly lower than the normal mean though still well within the normal range. ${ }^{11-15}$ In other studies the difference is not significant. ${ }^{16-18}$ An inverse relation between plasma volume and blood pressure is also reported in essential hypertension. ${ }^{12} 1415$ That observation was made originally by R. C. Tarazi and colleagues. ${ }^{14}$ Classifying their patients in a rather different way they found the correlation became less significant. ${ }^{19}$ They now propose $^{20}$ that blood pressure in certain types of essential hypertension is volume-dependent. During both sodium loading and sodium deprivation blood pressure and plasma volume correlated directly but, in the control period when untreated, there was no significant relation. Also needing explanation is the interesting paradox that blood pressure fell most during sodium deprivation in the group of patients with the lowest initial plasma volume. The case for volumedependent essential hypertension is not, therefore, clear-cut.

Some of these problems might be more clearly understood if evidence could be obtained in essential hypertension to support or refute the autoregulation theory. ${ }^{21}{ }_{22}$ According to this theory, which derives mainly from observations on animals, there is retention of sodium and water and expansion of volume in the early stages of hypertension. Increased cardiac output is mainly responsible for raising blood pressure at this stage.
Later, peripheral resistance rises (autoregulation of tissue perfusion), cardiac output falls, and plasma volume decreases. So it seems a period of volume expansion is followed by a more prolonged period of increased resistance. If this process occurs in patients with hypertension, the chances are that they will be clinically examined during the second phase, when volume is normal. It is of interest therefore that when peripheral resistance is raised in patients with essential hypertension plasma volume tends to be normal, and when cardiac output is high plasma volume tends to be high also. ${ }^{12}{ }^{15}{ }^{23}$ But much remains to be done before it is clear whether autoregulation occurs in essential hypertension and, if it does, whether it can account for the variations in plasma volume.

1 Douglas, B. H., Guyton, A. C., Langston, J. B., and Bishop, V. S., American fournal of Physiology, 1964, 207, 669.

2 Ledingham, J. M., and Pelling, D., Fournal of Physiology, 1970, 210, 233.

3 Blumberg, A., Nelp, W. B., Hegstrom, R. M., and Scribner, B. H., Lancet, 1967, 2, 69 .

de Planque, B. A., Mulder, E., and Dorhout Mees, E J., Acta Medica Scandinavica, 1969, 186, 75.

5 Wilkinson, R., Scott, D. F., Uidall, P. R., Kerr, D. N. S., and Swinney, J., Quarterly fournal of Medicine, 1970, 39, 377.

Carlberger, G., and Collste, L. G., Scandinavian fournal of Urology and Nephrology, 1968, 2, 151.

Biglieri, E. G., and Forsham, P. H., American fournal of Medicine, 1961, 30,564 .

${ }^{8}$ Brown, J. J., Davies, D. L., Lever, A. F., Peart, W. S., and Robertson, J. I. S., Fournal of Endocrinology, 1965, 33, 279.

Barraclough, M. A., American fournal of Medicine, 1966, 40, 265.

10 Goldberg, M., and McCurdy, D. K., Annals of Internal Medicine, 1963, $59,24$.

11 Ibsen, H., and Leth, A., Acta Medica Scandinavica, 1973, 194, 93.

12 Julius, S., Pascual, A. V., Reilly, K., and London, R., Archives of Internal Medicine, $1971,127,116$.

13 Tibblin, G., Bergentz, S. E., Bjure, J., and Wilhelmsen, L., American Heart fournal, 1966, 72, 165.

14 Tarazi, R. C., Frohlich, E. D., and Dustan, H. P., Newv England Fournal of Medicine, 1968, 278, 762 .

15 of Medicine, 1968, 278, 762.

16 Hansen, J., Acta Medica Scandinavica, 1968, 184, 517.

17 Cranston, W. I., and Brown, W., Clinical Science, 1963, 25, 107.

1 Walser, M., Duffy, B. J., and Griffith, H. W., Fournal of the American Medical Association, 1956, 160, 858.

19 Tarazi, R. C., Dustan, H. P., Frohlich, E. D., Gifford, R. W., and Hoffman, G. C., Archives of Internal Medicine, 1970, 125, 835.

20 Dustan, H. P., Bravo, E. L., and Tarazi, R. C., American fournal of Cardiology, 1973, 31, 606.

21 Ledingham, J. M., and Cohen, R. D., Lancet, 1963, 2, 979.

22 Coleman, T. G., and Guyton, A. C., Circulation Research, 1969, 25, 153.

23 Birkenhager, W. H., et al., European Journal of Clinical Investigation, $1972,2,115$.

\section{Turner's and Noonan's Syndromes}

During the past 35 years much has been learned about Turner's syndrome ${ }^{1}$ of webbing of the neck, cubitus valgus, and sexual infantilism in females. Additional features, such as short stature and congenital lymphoedema described by O. Ullich ${ }^{2}$ in an earlier paper, together with dysgenetic "streak" ovaries and abnormalities of the skin, kidneys, bones, and cardiovascular system are now generally recognized, and it is clear that there is considerable variation in the clinical expression of the syndrome. ${ }^{3}$ Early chromosome studies in such patients indicated that their cells carried a single $\mathrm{X}$ chromosome, ${ }^{4}$ but subsequent work has shown that mosaicism or a range of abnormalities of one sex chromosome may be present. ${ }^{5}$ It appears that the Turner phenotype is probably related to loss of genetic material on the short arm of one $X$ chromosome or corresponding areas of a Y chromosome. ${ }^{5}$

One aspect of Turner's syndrome which has been difficult to explain has been the occurrence in males of features of the syndrome similar to those originally described in women. ${ }^{6}$ In some cases, particularly those with ambiguous external genitalia, $\mathrm{XO} / \mathrm{XY}$ mosaicism has been present, but in the 